Review

\title{
Application of Oral Fluid Assays in Support of Mumps, Rubella and Varicella Control Programs
}

\author{
Peter A. C. Maple
}

East Yorkshire Microbiology, Innovation Centre, York Science Park, York YO10 5DG, UK;

E-Mail: eastyorksmicrobiol@gmail.com; Tel.: +44-0-1904-435-100; Fax: +44-0-1904-435-135

Academic Editor: Diane M. Harper

Received: 3 June 2015 / Accepted: 2 December 2015 / Published: 9 December 2015

\begin{abstract}
Detection of specific viral antibody or nucleic acid produced by infection or immunization, using oral fluid samples, offers increased potential for wider population uptake compared to blood sampling. This methodology is well established for the control of HIV and measles infections, but can also be applied to the control of other vaccine preventable infections, and this review describes the application of oral fluid assays in support of mumps, rubella and varicella national immunization programs. In England and Wales individuals with suspected mumps or rubella, based on clinical presentation, can have an oral fluid swab sample taken for case confirmation. Universal varicella immunization of children has led to a drastic reduction of chickenpox in those countries where it is used; however, in England and Wales such a policy has not been instigated. Consequently, in England and Wales most children have had chickenpox by age 10 years; however, small, but significant, numbers of adults remain susceptible. Targeted varicella zoster virus (VZV) immunization of susceptible adolescents offers the potential to reduce the pool of susceptible adults and oral fluid determination of VZV immunity in adolescents is a potential means of identifying susceptible individuals in need of VZV vaccination. The main application of oral fluid testing is in those circumstances where blood sampling is deemed not necessary, or is undesirable, and when the documented sensitivity and specificity of the oral fluid assay methodology to be used is considered sufficient for the purpose intended.
\end{abstract}

Keywords: mumps; rubella; varicella; immunization; oral fluid; antibody capture assays; time-resolved fluorescence immunoassay; genotyping; chickenpox history 


\section{Mumps: Mumps vaccination and Mumps Oral Fluid Testing}

\subsection{Mumps}

Mumps is a highly infectious, generally benign disease defined by acute onset of unilateral or bilateral tender, self-limited swelling of the parotid or other salivary glands, lasting two or more days and without other apparent cause [1]. A number of complications [2,3] can result following initial infection including orchitis ( $20 \%$ post pubertal young men), oophoritis ( $5 \%$ post pubertal young women), aseptic meningitis (15\%), encephalitis ( 1 in 6000) and pancreatitis (up to 5\%). Mumps is a common cause of acquired sensorineural hearing loss [4] usually of sudden onset, unilateral and reversible but in some cases nerve damage can result in permanent and profound hearing loss. There is some debate as to whether mumps acquired during the first trimester [5] results in a higher risk of spontaneous abortion.

The causative agent of mumps, the mumps virus, belongs to the family Paramyxoviridae, subfamily Paramyxovirinae, genus Rubulavirus. It is a non-segmented, negative strand RNA virus comprising a helical nucleocapsid surrounded by a lipid envelope. The complete genome of mumps virus has been sequenced [6] at 15,384 nucleotides long (Genbank accession no. AF2014730) and consists of seven different transcription units [7] including nucleoprotein (NP), membrane or matrix (M), fusion (F) and haemagglutinin-neuraminidase (HN) genes organized 3'-NP-P-M-F-SH-HN-L-5'. The HN glycoprotein [8] plays a major role in cell infection by the virus as it binds to sialic acid in host cell membranes thereby bringing about viral attachment which is followed by membrane fusion [9] and release of the viral nucleocapsid into the host cell.

Humans, so far as is known, are the only natural host of the mumps virus although animal species including hamster, mouse, developing chick embryo and non-human primates can be infected [10] under laboratory conditions. The incubation period of mumps ranges between 14 and 24 days (95\% cases) with a median of 18 days [11]. Epidemic transmission in humans is by droplet spread and it has been shown by virus culture [12] that in children infected with mumps virus, who subsequently developed parotitis, that virus can be recovered from saliva on the 11th to 15th day after exposure, two to six days prior to onset of clinical signs of disease and extending up to the fourth day of illness. Children with clinically non-apparent infection also shed mumps virus [12]. Using molecular techniques for detection of mumps virus following natural infection viral shedding was minimal after the first three days of symptoms [13].

Mumps is highly infectious and Philip et al. [14] in a unique study conducted during the late 1950s in which Eskimos residing on St. Lawrence Island first experienced a mumps outbreak showed an $88 \%$ attack rate. In the absence of mumps vaccination, reported mumps incidence in several countries of the WHO European region ranged up to $>400$ cases per 100,000 [15] in epidemic years and in the USA an annual incidence of approximately 2000 cases per 100,000 population has been reported [16]. Typically, in the prevaccine era there were epidemic periods every two to five years with children aged five to nine years most affected. The implementation of population based mumps vaccination changed all of this.

\subsection{Mumps Vaccination}

Mumps vaccination was first practiced during the 1940s using both live attenuated and inactivated vaccine preparations and it was shown that a significant reduction in the incidence of mumps in vaccinated versus control groups could be achieved and that mumps occurring in previously vaccinated 
individuals was of reduced severity [17]. The first of the attenuated mumps vaccines which currently underpin national immunization programs became available during the 1960s. The Jeryl Lynn vaccine strain, licensed in the USA in 1967, was developed from mumps virus isolated from a child who had developed unilateral parotitis and subsequently passaged in chick embryo amniotic cavity followed by chick embryo fibrobasts [18]. A number of other mumps virus vaccine strains have been developed and used for example, Leningrad-3, Urabe, Leningrad Zagreb and Rubini; however, there have been reports of aseptic meningitis and lack of immunogenicity for some of them [15,19].

In England and Wales, a national immunization program using one dose of a combined measles, mumps and rubella (MMR) vaccine given to children 12-15 months of age was commenced in 1988 and in 1996 a second dose was added, given at school entry [20]. Many countries have implemented MMR vaccination into their national immunization programs and in many cases a $>90 \%$ reduction in mumps annual incidence has been achieved [21]. Unfortunately, despite the undeniable success of mumps immunisation using two doses of MMR there have been reports of a resurgence of mumps in highly vaccinated populations; for example in the UK, USA, Netherlands and Korea [22-25]. No single factor has been identified as the cause of these outbreaks although waning immunity in older vaccinated populations [26], incomplete vaccine coverage and differences in the immunogenicity of vaccine strains, e.g., Rubini [27] have been implicated as factors.

\subsection{Application of Oral Fluid Testing to Mumps Control}

The detection of mumps specific $\operatorname{IgM}$ in oral fluids using capture radioimmunoassay has been available since the early 1990s [28] and in England and Wales laboratory confirmation of mumps as a component of a national MMR surveillance program has been undertaken since 1994 [20,29]. Subsequently, mumps IgM radioimmunoassay was replaced by enzyme immunoassay [30] and detection of mumps RNA in oral fluid samples collected during the first 14 days after onset of symptoms is also possible [31]. Oral fluid sampling has a number of advantages over venipuncture, principally it is non-invasive and collection can be undertaken by unskilled staff or by the subject following a set of written instructions [32,33]. Other advantages are that oral fluid sampling is more accessible than blood sampling and there are no "sharps" to be disposed of post sampling removing the risk of contaminated needle injuries and repeated use of contaminated equipment. A number of commercial oral fluid collection devices are available [34,35] and particularly for HIV diagnosis/surveillance oral fluid testing has become a firmly established methodology [36,37]. A major advantage of oral fluid testing is that it increases sampling in difficult to access populations [38,39] and for MMR case confirmation/surveillance this is an important factor in modeling the impact of immunization programs [40].

In England and Wales the Oracol oral fluid collection device is frequently used for MMR surveillance [20,34]. The device (Figure 1), either handed or posted to the test subject, comprises a sampling swab supplied with instructions for the collection of oral fluid. The subject is advised to rub the gums and teeth with the sponge head of the swab, a bit like using a toothbrush, for one to two minutes. The swab is then placed within the labeled plastic swab holder tube, capped, placed in a sealable clear plastic bag, and placed together with a completed requested form into a transport cardboard container. Finally, the transport container is placed within a pre-paid and labeled plastic envelope which can then be posted to the testing laboratory. 


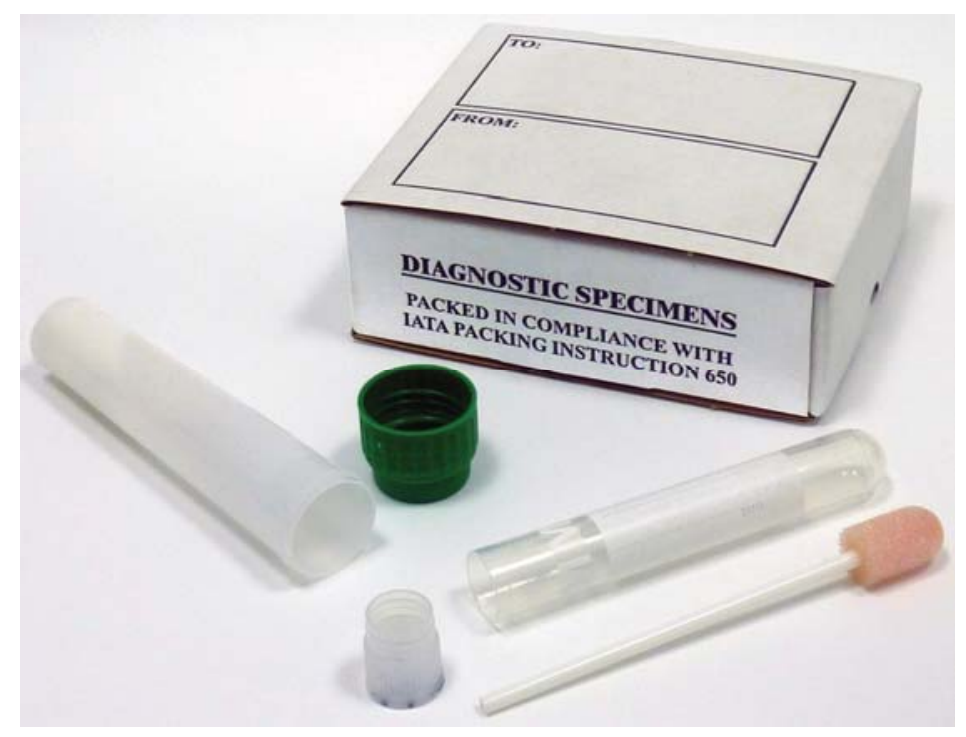

Figure 1. A mumps oral fluid collection kit comprising Oracol collection swab and transport packaging.

Testing of oral fluid for the presence of specific antibody IgG or IgM requires the use of highly sophisticated assay methodologies because the amount of specific antibody in the oral fluid sample is much less that that found within a comparable blood sample [41]. Initially, the requirement for highly sensitive detection methodologies (e.g., radioimmunoassay, time-resolved fluorescence immunoassay) limited the performance of oral fluid assays to specialized laboratories; however, commercially produced enzyme immunoassays are now available (e.g., Microimmune) and point of care tests are under development [42]. In comparison with blood based detection methodologies mumps oral fluid assays may sometimes show significantly reduced sensitivity [43]; however, in most instances sensitivity and specificity has been shown to be acceptable (Table 1).

Table 1. Reported performance of mumps oral fluid enzyme immunoassays (EIAs) and near patient tests.

\begin{tabular}{cccc}
\hline Assay & Population Tested & Sensitivity & Specificity \\
\hline IgG EIA (Clark Laboratories & 157 asymptomatic subjects [44] & $94.2 \%$ & $93.9 \%$ \\
IgG capture EIA (Microimmune) & 340 Norwegian conscripts [43] & $80.0 \%$ & $100 \%$ \\
IgM capture EIA (Microimmune) & 137 cases of suspected mumps [30] & $90.3 \%$ & $97.6 \%$ \\
IgM near patient test & 196 cases of suspected mumps [42] & $79.5 \%$ & $100 \%$ \\
\hline
\end{tabular}

Mumps oral fluid testing offers an effective means for screening the incidence of mumps and estimating levels of vaccine coverage $[44,45]$ essential for monitoring the effectiveness of national control programs. An added advantage of oral fluid sampling is that viral RNA can be amplified [46] and genotyped [47] facilitating outbreak investigation and surveillance of mumps [47,48]. The European Region of the World Health Organization (WHO) had set a target for the reduction of the incidence of mumps to negligible levels by 2010; however, this goal remains to be achieved [49]. Mumps still proves a challenging disease to effectively control and a range of measures [50] including better ascertainment of mumps infection and vaccine effectiveness together with the potential development of new mumps vaccines will be required if mumps elimination targets are to be achieved. 


\section{Rubella: Rubella Vaccination and Rubella Oral Fluid Testing}

\subsection{Rubella}

First described in 1814 and initially known as German Measles (Rötheln) until 1866 when the term "rubella" was proposed, this infection was viewed as an intermediate between measles and scarlatina [51]. By the later stages of the nineteenth century rubella was generally accepted nomenclature for some authorities; however, the descriptive German Measles was retained by others. In The Diseases of Children Medical and Surgical published 1889 [52] rubella was ascribed as an infectious fever closely resembling but distinct from measles and scarlatina and it had been observed that despite clinical similarities rubella offered no protection against subsequent measles and scarlatina and vice versa. Rubella frequently occurred in epidemics, had an incubation period of 14-21 days and produced confluent indistinct papules of a rose-red colour following no or an indistinct prodrome lasting one day. The potential linkage of rubella infection during pregnancy with congenital cataract and failure to thrive of the newborn combined with a high risk of congenital heart defects was first proposed by a Sydney based ophthalmologist, Sir Norman McAlister Gregg in 1941 [53]. In the cohort of patients he reviewed with the aforementioned clinical presentations he observed that most cases occurred following maternal rubella during the first two months of pregnancy and advised that exposure of the mother to infection of any kind during the entire period of pregnancy should be recorded. This truly novel finding, based on meticulous history taking, that a virus infection in humans could manifest an embryopathy was not at first universally accepted [54,55]. A limitation of Gregg's data was that it was retrospective; however, subsequent observations of others and prospective studies [56] confirmed his hypothesis. The rate of congenital malformation following maternal rubella early in pregnancy has been shown to be very high; for example, Miller and colleagues [57] reported rubella defects in all infants infected before the 11th week of gestation.

Nowadays, with the availability of enhanced techniques for rubella virus cultivation [58], plus the availability of highly sensitive serological and molecular detection methodologies [59] combined with the ability to undertake genomic analysis [60] much more is understood about rubella and how it is spread. The rubella virus is a positive-sense, single-stranded RNA virus that belongs to the family Togaviridae and is the only member of the genus, Rubivirus. Comprising 9762 nucleotides a number of virus isolates have been whole genome sequenced [61]. The rubella virus is formed of a nucleocapsid enveloped by lipoprotein through which spikes of glycoproteins E1 and E2 protrude [62] and there are a number of non-structural proteins [63]. Both capsid and envelope glycoproteins have been shown to be immunogenic and E2 appears immunodominant [64]. Only one serotype of rubella virus appears to exist although there are a number of genotypes [65] and the virus host range is restricted to humans.

\subsection{Rubella Vaccination}

The clinical and laboratory diagnosis of rubella and congenital rubella syndrome together with the development of rubella vaccines [66,67] has been extensively reviewed elsewhere. Before the introduction of rubella vaccination into national immunization programs rubella infection occurred in endemic and epidemic waves [68] some of which were very severe. For instance, in the USA major epidemics occurred throughout the country in 1935, 1943 and 1964 against a background of periods of 
high incidence every six to nine years [69] During the 1964-1965 rubella epidemic in the USA there were an estimated 12,500,000 cases of rubella resulting in 159,375 cases of arthritis/arthralgia and 20,000 cases of congenital rubella syndrome [70]. The widespread use of rubella vaccination from the 1970s onwards, using differing strategies, has led to development of the goal of eradication of rubella and congenital rubella syndrome and in some countries this was achieved by the end of the last Century [71]. Recently, the World Health Assembly endorsed the target of eliminating rubella in five of the six World Health Organisation regions by 2020 to be achieved through the promotion of measles and rubella vaccination programmes combined with active surveillance for rubella and assessment of rubella immunity using a variety of methodologies including the potential use of oral fluid assays [72].

\subsection{Application of Oral Fluid Testing to Rubella Control}

Laboratory methodologies for diagnosing rubella and measuring immunity have been reviewed elsewhere [67,73] Evidence of the potential for using oral fluid samples for the detection of rubella specific IgG was first presented by Parry and colleagues [74] who tested a collection of 30 paired sera and oral fluids. Their initial findings were followed up in more detail by Perry and colleagues [28] who tested 150 oral fluid samples from patients with serologically confirmed rubella using a class $\mathrm{G}$ antibody capture radioimmunoassay (GACRIA). The GACRIA had 100\% sensitivity for oral fluid samples collected four or more days following the onset of illness; however, the sensitivity reduced to $30 \%-47 \%$ for oral fluid samples collected approximately three months post onset of illness. Subsequently, the rubella GACRIA gave promising results when applied in a survey of response to rubella vaccination in Brazilian children [75]; and in a study of confirmation of notified cases of rubella in the United Kingdom over the period 1991-1994 [76]; Unfortunately, other studies [77,78] showed that reduction of assay sensitivity with age was an ongoing issue. In a later study [79], 197 paired sera and oral fluid samples from infants, children and adults were tested using a class $\mathrm{G}$ capture amplification-based enzyme-linked immunosorbent assay (GACELISA) and the aforementioned GACRIA. The GACELISA performed better than the GACRIA; however, with adult samples sensitivity was only $60.8 \%$. The issue of declining assay sensitivity with age when using class G antibody capture immunoassays lacks adequate explanation and remains to be resolved although application of enhanced modeling techniques may help alleviate the problem [80]. The possibility of using a completely different assay design for measuring rubella IgG in oral fluid samples has been explored by Ben Salah and colleagues [81]. In their study an indirect enzyme immunoassay format (Behring ELISA) was compared with GACELISA for detecting rubella $\mathrm{IgG}$ in an age stratified population. Using an optimized cut-off the sensitivity of the Behring ELISA was $89.8 \%$ and specificity was $92.0 \%$ compared to GACELISA optimised sensitivity and specificity of $92.4 \%$ and $93.2 \%$ respectively. Further studies are needed to confirm the utility of an indirect EIA format for rubella IgG detection in oral fluids and it will be seen in Section 3.3 that time-resolved fluorescence immunoassay can offer the sensitivity required. A rubella IgG time-resolved fluorescence immunoassay has been described [82] with a lower limit of detection of $0.2 \mathrm{IU} / \mathrm{mL}$ in sera and initial results on application to oral fluid appear promising.

The role of oral fluid assays for rubella $\operatorname{IgM}$ detection is more established [72,83] and these assays have found application in rubella surveillance and control. In rubella low incidence settings the potential for rubella misdiagnosis is high [84,85] and this is why, in the United Kingdom, a rubella oral fluid 
testing program has run since 1994 [86]. During January 1995-July 2003, 17,042 oral fluid samples from cases of clinically suspected rubella were tested as part of the program and the rate of case confirmation was $51 \%$ and the specificity was $55 \%$ [87]. The performance of oral fluid tests for rubella IgM detection is summarized in Table 2.

Table 2. Reported performance of rubella class IgM capture radioimmunoassays (MACRIA) and enzyme immunoassays (MACEIA).

\begin{tabular}{|c|c|c|c|}
\hline Assay & Population Tested & Sensitivity & Specificity \\
\hline $\begin{array}{l}\text { Rubella } \\
\text { MACRIA }\end{array}$ & $\begin{array}{l}\text { Paired sera and oral fluids from } 50 \text { clinically diagnosed and } \\
\text { serologically confirmed rubella cases and } 91 \text { paired sera and oral } \\
\text { fluids from blood donors [28] }\end{array}$ & $\begin{array}{c}100 \% 1 \text { day }-5 \text { weeks } \\
\text { post onset }\end{array}$ & $100 \%$ \\
\hline $\begin{array}{c}\text { Rubella } \\
\text { MACRIA }\end{array}$ & $\begin{array}{l}\text { Paired sera and oral fluids from } 177 \text { cases of notified rubella: } 53 \\
\text { confirmed IgM positive by serology of paired serum and } 124 \\
\text { confirmed IgM negative by serology [78] }\end{array}$ & $81 \%$ & $99 \%$ \\
\hline $\begin{array}{l}\text { Rubella } \\
\text { MACRIA }\end{array}$ & $\begin{array}{l}\text { Paired sera and oral fluids from } 45 \text { clinically diagnosed and } \\
\text { serologically confirmed rubella cases and } 149 \text { paired sera and } \\
\text { oral fluids from individuals with other non-rubella recent rash } \\
\text { diseases [88] }\end{array}$ & $84.4 \%$ & $96 \%$ \\
\hline $\begin{array}{c}\text { Rubella } \\
\text { MACEIA } \\
\text { (Commercial) }\end{array}$ & $\begin{array}{l}\text { Paired sera and oral fluids from } 55 \text { rubella cases from outbreak } \\
\text { in Turkey and } 111 \text { paired sera and oral fluids from suspected } \\
\text { congenital rubella syndrome cases in India [89] }\end{array}$ & $>95 \%$ & $>95 \%$ \\
\hline
\end{tabular}

Oral fluids, if collected soon enough following onset of illness and appropriately stored prior to testing are a valuable source of rubella virus genome which can be amplified by reverse transcription polymerase chain reaction (RT-PCR) and used to complement the results of antibody testing or sequenced so that the spread of virus can be tracked [31,90,91]. In a definitive study [92], Abernathy and colleagues showed that rubella RT-PCR testing of oral fluid confirmed more rubella cases than IgM testing of either serum or oral fluid samples collected in the first two days following rash onset and that the maximum number of confirmations of rubella cases was obtained by combining rubella RT-PCR and serology testing. Likewise, the value of virological surveillance for rubella using rubella RT-PCR to amplify viral genome in samples including oral fluids has been reviewed by Rota and colleagues [93].

\section{Varicella: varicella vaccination and varicella oral fluid testing}

\subsection{Varicella}

Primary infection with varicella zoster virus (VZV) manifests as varicella (chickenpox) and reactivation later in life produces herpes zoster (shingles). In the UK, traditionally, most cases of varicella occurred in 5-14 year olds; however, in recent years there has been a sharp increase in the prevalence of varicella in 1-4 year olds so that most cases, now, are reported in children aged $0-5$ years $[94,95]$. Primary varicella infection in healthy children is generally a mild, self-limiting disease which typically presents as a cropping vesicular rash; however, in immunocompromised individuals and susceptible adults, particularly pregnant women, the infection can be more serious and even life threatening [96,97]. Finally, varicella infection during the first 20 weeks of pregnancy can result in 
miscarriage or foetal development anomalies (congenital varicella syndrome) while infection during the peripartum period can result in neonatal varicella which has a significant mortality rate [98].

\subsection{Varicella Vaccination}

An effective vaccine against varicella has been available for a number of years and universal childhood vaccination is undertaken in a number of countries (e.g., USA, Germany, Japan) although not the UK [99]. The UK policy of not introducing universal varicella immunisation is, in part, motivated by concerns that such a measure may shift the burden of primary disease to susceptible adults and increase shingles reactivations in later life due to a reduction in natural boosting in previously exposed individuals [100]. Targeted varicella immunisation strategies, instead of universal varicella vaccination of children, may have potential for preventing severe primary infections among adults. In the UK, selective varicella vaccination of susceptible adolescents is under active consideration [101]. An essential component for modelling the potential effectiveness of targeted vaccination and for monitoring trends in disease epidemiology is the capacity to accurately estimate the extent of VZV infection at a population level. Two methodologies are chiefly used to generate such estimates - serosurvey of VZV immunity [102] and recall of a history of chickenpox [103].

\subsection{Application of Oral Fluid Testing to Varicella Control}

Detection of VZV IgG in serum, using appropriately validated methods (e.g., fluorescent antibody to membrane antigen immunofluorescence assay_FAMA), has been shown [104,105] to correlate with a history chickenpox or vOka vaccination. FAMA is not amenable for testing large numbers of sera and is highly subjective, so alternative methodologies such as quantitative, standardised, VZV time-resolved fluorescence immunoassay [106,107] have been developed. For population based studies of immunity to VZV the logistics required to collect blood and the invasive nature of collecting blood samples are prohibitive. In addition, sero-surveys using stored blood samples, particularly from children, have the potential for bias as such samples are often collected for highly specific medical investigations. The utility of recall of history of chickenpox has been evaluated in a number of settings $[108,109]$. A number of studies have shown that recall of history of chickenpox is highly associated with serological evidence of chickenpox [110,111] and that no history of chickenpox has low association with a lack of serological evidence of chickenpox [112,113].

Detection of VZV IgG using oral fluid samples removes the biases and limitations associated with blood sampling or the need to rely upon uncertain recall of no history of chickenpox. Such an approach can be used to identify susceptible individuals as part of targeted vaccination initiatives. In a study of adolescents [114] use of a time-resolved fluorescence immunoassay to detect VZV IgG in oral fluid samples showed that significant vaccine wastage might occur if reported absence of history of chickenpox was used to determine the need for varicella vaccination. Serological testing followed by immunization of certain population groups without a history of chickenpox may prove cost effective [115,116] and oral fluid sampling may find useful application in these circumstances. 


\section{Conclusions}

This review shows that oral fluid sampling and analysis can be of significant value in supporting disease control programmes and monitoring the impact of interventions such as vaccination. The technology for undertaking oral fluid analysis is currently highly specialised and only available at a limited number of laboratories and although such testing is of great value the lack of availability of more readily accessible assays can be seen as a drawback to deriving the full benefits of collecting these samples [84]. There is little reason to doubt that at the current rate of technological development, if the desire is sufficient, there will be an expansion in the availability of oral fluid testing kits, such as is the case with HIV oral fluid testing in the USA; however, it remains to be determined if such devices can achieve acceptable diagnostic accuracies compared to testing of fingerprick blood samples or blood collected by venepuncture [117]. The main application of oral fluid testing is in those circumstances where blood sampling is deemed not necessary, or is undesirable, and when the documented sensitivity and specificity of the oral fluid assay methodology to be used is considered sufficient for the purpose intended.

\section{Acknowledgments}

My thanks to Jon White, Medical Illustration, Public Health England, Colindale, London for photograph of oral fluid collection kit.

\section{Conflicts of Interest}

The author declares no conflict of interest.

\section{References}

1. Senanayake, S.N. Mumps: A resurgent disease with protean manifrstations. Med. J. Aust. 2008, 189, 456-459.

2. Gupta, R.K.; Best, J.; MacMahon, E. Mumps and the UK epidemic 2005. Br. Med. J. 2005, 330, 1132-1135.

3. Yung, C.F.; Andrews, N.; Bukasa, A.; Brown, K.E.; Ramsay, M. Mumps complications and effects of mumps vaccination, England and Wales, 2002-2006. Emerg. Infect. Dis. 2011, 17, 661-667.

4. Cohen, B.E.; Durstenfeld, A.; Roehm, P.C. Viral causes of hearing loss: A review for hearing health professionals. Trends Hear. 2014, 18, 1-17.

5. Enders, M.; Rist, B.; Enders, G. Frequency of spontaneous abortion and premature birth after acute mumps infection in pregnancy. Gynäkol. Geburtshilfliche Rundsch. 2005, 45, 39-43.

6. Clarke, D.K.; Sidhu, M.S.; Johnson, J.E.; Udem, S.A. Rescue of mumps virus from cDNA. J. Virol. 2000, 74, 4831-4838.

7. Elango, N.; Varsanyi, T.M.; Kovamees, J.; Norrby, E. Molecular cloning and characterization of six genes, determination of gene order and intergenic sequences and leader sequence of mumps virus. J. Gen. Virol. 1988, 69, 2893-2900.

8. Jensik, S.C.; Silver, S. Polypeptides of mumps virus. J. Virol. 1976, 17, 363-373.

9. Lamb, R.A.; Paterson, R.G.; Jardetzky, T.S. Paramyxovirus membrane fusion: Lessons from the F and $\mathrm{HN}$ atomic structures. Virology 2006, 344, 30-37. 
10. Rubin, S.; Eckhaus, M.; Rennick, L.J.; Bamford, C.C.G.; Duprex, W.P. Molecular biology, pathogenesis and pathology of mumps virus. J. Pathol. 2015, 235, 242-252.

11. Meyer, M.B. An epidemiologic study of mumps: Its spread in schools and families. Am. J. Hyg. 1962, 75, 259-281.

12. Henle, G.; Henle, W.; Wendell, K.K.; Rosenberg, P. Isolation of mumps virus from human beings with induced apparent or inapparent infections. J. Exp. Med. 1948, 88, 223-232.

13. Bitsko, R.H.; Cortese, M.M.; Dayan, G.H.; Rota, P.A.; Lowe, L.; Iversen, S.C.; Bellini, W.J. Detection of RNA of mumps virus during an outbreak in a population with a high level of measles, mumps, and rubella vaccine coverage. J. Clin. Microbiol. 2008, 46, 1101-1103.

14. Philip, R.N.; Reinhard, K.N.; Lackman, D.B. Observations on a mumps epidemic in a "virgin" population. Am. J. Hyg. 1959, 69, 91-110.

15. Edmunds, W.J.; Gay, N.J.; Kretzschmar, M.; Pebody, R.G.; Wachmann, H. The pre-vaccination epidemiology of measles, mumps and rubella in Europe: Implications for modelling studies. Epidemiol. Infect. 2000, 125, 635-650.

16. Levitt, L.P.; Mahoney, D.H., Jr.; Casey, H.L.; Bond, J.O. Mumps in a general population. A sero-epidemiologic study. Am. J. Dis. Child. 1970, 120, 134-138.

17. Habel, K. Vaccination of human beings against mumps: Vaccine administered at the start of an epidemic. I. Incidence and severity of mumps in vaccinated and control groups. Am. J. Hyg. 1951, 54, 295-311.

18. Buynak, E.B.; Hilleman, M.R. Live attenuated mumps virus vaccine: 1. Vaccine development. Proc. Soc. Exp. Biol. Med. 1966, 123, 768-775.

19. Minor, P.D. Live attenuated vaccines: Historical successes and current challenges. Virology 2015, doi:10.1016/j.virol.2015.03.032.

20. Vyse, A.J.; Gay, N.J.; White, J.M.; Ramsay, M.E.; Brown, D.W.G.; Cohen, B.J.; Hesketh, L.M.; Morgan-Capner, P.; Miller, E. Evolution of surveillance of measles, mumps, and rubella in England and Wales: Providing the platform for evidence-based vaccination policy. Epidemiol. Rev. 2002, 24, 125-136.

21. Galazka, A.M.; Robertson, S.E.; Kraigher, A. Mumps and mumps vaccine: A global review. Bull. World Health Organ. 1999, 77, 3-14.

22. Savage, E.; Ramsay, M.; White, J.; Beard, S.; Lawson, H.; Hunjan, R.; Brown, D. Mumps outbreaks across England and Wales in 2004: Observational study. Br. Med. J. 2005, 330, 1119-1120.

23. Livingston, K.A.; Rosen, J.B.; Zucker, J.R.; Zimmerman, C.M. Mumps vaccine effectiveness and risk factors for disease in households during an outbreak in New York City. Vaccine 2014, 32, 369-374.

24. Sane, J.; Gouma, S.; Koopmans, M.; de Melker, H.; Swaan, C.; van Binnendijk, R.; Hahné, S. Epidemic of mumps among vaccinated persons, the Netherlands, 2009-2012. Emerg. Infect. Dis. 2014, 20, 643-648.

25. Park, S.H. Resurgence of mumps in Korea. Infect. Chemother. 2015, 47, 1-11.

26. Cohen, C.; White, J.M.; Savage, E.J.; Glynn, J.R.; Choi, Y.; Andrews, N.; Brown, D.; Ramsay, M.E. Vaccine effectiveness estimates, 2004-2005 mumps outbreak, England. Emerg. Infect. Dis. 2007, $13,12-17$. 
27. Dayan, G.H.; Rubin, S. Mumps outbreaks in vaccinated populations: Are available mumps vaccines effective enough to prevent outbreaks? Clin. Infect. Dis. 2008, 47, 1458-1467.

28. Perry, K.R.; Brown, D.W.G.; Parry, J.V.; Panday, S.; Pipkin, C.; Richards, A. Detection of measles, mumps and rubella antibodies in saliva using antibody capture radioimmunoassay. J. Med. Virol. 1993, 40, 235-240.

29. Ramsay, M.; Brugha, R.; Brown, D. Surveillance of measles in England and Wales: Implications of a national saliva testing programme. Bull. World Health Organ. 1997, 75, 515-521.

30. Warrener, L.; Samuel, D. Evaluation of a commercial assay for the detection of mumps specific IgM antibodies in oral fluid and serum specimens. J. Clin. Virol. 2006, 35, 130-134.

31. Jin, L.; Vyse, A.; Brown, D.W.G. The role of RT-PCR assay of oral fluid for diagnosis and surveillance of measles, mumps and rubella. Bull. World Health Organ. 2002, 80, 76-77.

32. Bartington, S.E.; Peckham, C.; Brown, D.; Joshi, H.; Dezateux, C.; Millenium Cohort Study Child Health Group. Feasibility of collecting oral fluid samples in the home setting to determine seroprevalence of infections in a large-scale cohort of preschool-aged children. Epidemiol. Infect. 2009, 137, 211-218.

33. Ochnio, J.J.; Scheifele, D.W.; Marion, S.A.; Bigham, M.; Patrick, D.M.; Ho, M.; Mozel, M. Participant-collected, mail-delivered oral fluid specimens can replace traditional serosurveys: A demonstration-of-feasibility survey of hepatitis A virus-specific antibodies in adults. Can. J. Public Health 2007, 98, 37-40.

34. Vyse, A.J.; Cohen, B.J.; Ramsay, M.E. A comparison of oral fluid collection devices for use in the surveillance of virus diseases in children. Public Health 2001, 115, 201-207.

35. Tourinho, R.S.; de Almeida, A.J.; Amado, L.A.; Villar, A.M.; Castro, A.R.; de Paula, V.S. Could oral fluid be used to evaluate anti-hepatitis A virus status in individuals living in difficult-to-access areas? Vaccine 2012, 30, 6421-6426.

36. Masciotra, S.; Smith, A.J.; Youngpairoj, A.S.; Sprinkle, P.; Miles, I.; Sionean, C.; Paz-Bailey, G.; Johnson, J.A.; Owen, S.M. Evaluation of the CDC proposed laboratory HIV testing algorithm among men who have sex with men (MSM) from five US metropolitan statistical areas using specimens collected in 2011. J. Clin. Virol. 2013, 58, e8-e12.

37. Weidle, P.J.; Lecher, S.; Botts, L.W.; Jones, L.; Spach, D.H.; Alvarez, J.; Jones, R.; Thomas, V. HIV testing in community pharmacies and retail clinics: A model to expand access to screening for HIV infection. J. Am. Pharm. Assoc. 2003, 54, 486-492.

38. Maple, P.A.C.; Simms, I.; Kafatos, G.; Solomou, M.; Fenton, K. Application of a noninvasive oral fluid test for detection of treponemal IgG in a predominantly HIV-infected population. Eur. J. Clin. Microbiol. Infect. Dis. 2006, 25, 743-749.

39. Sherman, G.G.; Jones, S.A. Oral fluid human immunodeficiency virus tests: Improved access to diagnosis for infants in poorly resourced prevention of mother to child transmission programs. Pediatr. Infect. Dis. J. 2005, 24, 253-256.

40. Brown, D.W.G.; Ramsay, M.E.B.; Richards, A.F.; Miller, E. Salivary diagnosis of measles: A study of notified cases in the United Kingdom, 1991-1993. Br. Med. J. 1994, 308, 1015-1017.

41. McKie, A.; Vyse, A.; Maple, C. Novel methods for the detection of microbial antibodies in oral fluid. Lancet Infect. Dis. 2002, 2, 18-24. 
42. Warrener, L.; Slibinskas, R.; Brown, D.; Sasnauskas, K.; Samuel, D. Development and evaluation of a rapid immunochromatographic test for mumps-specific IgM in oral fluid specimens and use as a matrix for preserving viral nucleic acid for RT-PCR. J. Med. Virol. 2010, 82, 485-493.

43. Vainio, K.; Samdal, H.H.; Anestad, G.; Wedege, E.; Skutlaberg, D.H.; Bransdal, K.T.; Mundal, R.; Aaberge, I.S. Detection of measles- and mumps-specific IgG antibodies in paired serum and oral fluid samples from Norwegian conscripts. Eur. J. Clin. Microbiol. Infect. Dis. 2008, 27, 461-465.

44. Thieme, T.; Placentini, S.; Davidson, S.; Steingart, K. Determination of measles, mumps, and rubella immunization status using oral fluid samples. J. Am. Med. Assoc. 1994, 272, 219-221.

45. Dittrich, S.; Hahné, S.; van Lier, A.; Kohl, R.; Boot, H.; Koopmans, M.; van Binnendijk, R. Assessment of serological evidence for mumps virus infection in vaccinated children. Vaccine 2011, 29, 9271-9275.

46. Jin, L.; Feng, Y.; Parry, R.; Cui, A.; Lu, Y. Real-time PCR and its application to mumps rapid diagnosis. J. Med. Virol. 2007, 79, 1761-1767.

47. Jin, L.; Brown, D.W.G.; Litton, P.A.; White, J.M. Genetic diversity of mumps virus in oral fluid specimens: Application to mumps epidemiological study. J. Infect. Dis. 2004, 189, 1001-1008.

48. Reid, F.; Hassan, J.; Irwin, F.; Waters, A.; Hall, W.; Connell, J. Epidemiologic and diagnostic evaluation of a recent mumps outbreak using oral fluid samples. J. Clin. Virol. 2008, 41, 134-137.

49. Eriksen, J.; Davidkin, I.; Kafatos, G.; Andrews, N.; Barbara, C.; Cohen, D.; Duks, A.; Griskevicius, A.; Johansen, K.; Bartha, K.; et al. Seroepidemiology of mumps in Europe (1996-2008): Why do outbreaks occur in highly vaccinated populations? Epidemiol. Infect. 2013, 141, 651-666.

50. Plans, P. New preventive strategy to eliminate measles, mumps and rubella from Europe based on the serological assessment of herd immunity levels in the population. Eur. J. Clin. Microbiol. Infect. Dis. 2013, 32, 961-966.

51. Cooper, L.Z. The history and medical consequences of rubella. Rev. Infect. Dis. 1985, 7, S2-S10.

52. Ashby, H.; Wright, G.A. The Diseases of Children: Medical and Surgical, 1st ed.; Longmans, Green, and Co.: London, UK, 1889; pp. 233-236.

53. Gregg, N.M. Congenital cataract following German measles in the mother. Trans. Ophthalamol. Soc. Aust. 1941, 3, 35-46.

54. Parsons, L.G. Congenital defects from German measles. Lancet 1946, 247, 201-202.

55. Robin, I.G. Congenital defects from maternal rubella. Lancet 1952, 260, 1034.

56. Greenberg, M.; Pellitteri, O.; Barton, J. Frequency of defects in infants whose mothers had rubella during pregnancy. J. Am. Med. Assoc. 1957, 165, 675-678.

57. Miller, E.; Cradock-Watson, J.E.; Pollock, T.M. Consequences of confirmed maternal rubella at successive stages of pregnancy. Lancet 1982, 2, 781-784.

58. Feng, Y.; Santibanez, S.; Appleton, H.; Lu, Y.; Jin, L. Application of new assays for rapid confirmation and genotyping of isolates of rubella virus. J. Med. Virol. 2011, 83, 170-177.

59. Jin, L.; Thomas, B. Application of molecular and serological assays to case based investigations of rubella and congenital rubella syndrome. J. Med. Virol. 2007, 79, 1017-1024.

60. Yasui, Y.; Mori, Y.; Adachi, H.; Kobayashi, S.; Yamashita, T.; Minagawa, H. Detection and genotyping of rubella virus from exanthematous patients suspected of having measles using reverse transcription-PCR. Jpn. J. Infect. Dis. 2014, 67, 389-391. 
61. Abernathy, E.; Chen, M.-H.; Bera, J.; Shrivastava, S.; Kirkness, E.; Zheng, Q.; Bellini, W.; Icenogle, J. Analysis of whole genome sequences of 16 strains of rubella virus from the United States, 1961-2009. Virol. J. 2013, doi:10.1186/1743-422X-10-32.

62. Battisti, A.J.; Yoder, J.D.; Plevka, P.; Winkler, D.C.; Prasad, V.M.; Kuhn, R.J.; Frey, T.K.; Steven, A.C.; Rossmann, M.G. Cryo-electron tomography of rubella virus. J. Virol. 2012, 86, 11078-11085.

63. Forng, R.-Y.; Frey, T.L. Identification of the rubella virus nonstructural proteins. Virology 1995, 206, 843-853.

64. Chave, H.H.; Mauracher, C.A.; Tingle, A.J.; Gillam, S. Cellular and humoral immune responses to rubella virus structural proteins E1, E2, and C. J. Clin. Microbiol. 1992, 30, 2323-2329.

65. Abernathy, E.S.; Hübschen, J.M.; Muller, C.P.; Jin, L.; Brown, D.; Komase, K.; Mori, Y.; Xu, W.; Zhu, Z.; Siqueira, M.M.; et al. Status of global virologic surveillance for rubella viruses. J. Infect. Dis. 2011, 204, S524-S532.

66. Best, J.M. Rubella. Semin. Fetal Neonatal Med. 2007, 12, 182-192.

67. Best, J.M. Rubella vaccines: Past, present and future. Epidemiol. Infect. 1991, 107, 17-30.

68. Galazka, A. Rubella in Europe. Epidemiol. Infect. 1991, 107, 43-54.

69. Witte, J.J.; Karchmer, A.W.; Herrmann, K.L.; Abrutyn, E.; Kassanoff, I.; Neill, J.S. Epidemiology of rubella. Am. J. Dis. Child. 1969, 118, 107-111.

70. Plotkin, S.A. Rubella eradication. Vaccine 2001, 19, 3311-3319.

71. Plotkin, S.A.; Katz, M.; Cordero, J.F. The eradication of rubella. J. Am. Med. Assoc. 1999, 281, 561-562.

72. Lambert, N.; Strebel, P.; Orenstein, W.; Icenogle, J.; Poland, G.A. Rubella. Lancet 2015, 385, 2297-2307.

73. Best, J.M.; Reef, S. The Immunological Basis for Immunization Series, Module 11: Rubella; World Health Organization: Geneva, Switzerland, 2008.

74. Parry, J.V.; Perry, K.R.; Mortimer, P.P. Sensitive assays for viral antibodies in saliva. Lancet 1987, 2, 72-75.

75. De Azevedo Neto, R.S.; Richards, A.; Nokes, D.J.; Silveira, A.S.; Cohen, B.J.; Passos, S.D.; de Souza, V.A.; Brown, D.W.; Pannuti, C.S.; Massad, E. Salivary antibody detection in epidemiological surveys: A pilot study after a mass vaccination campaign against rubella in São Paulo, Brazil. Trans. R. Soc. Trop. Med. Hyg. 1995, 89, 115-118.

76. Nokes, D.J.; Enquselassie, F.; Vyse, A.; Nigatu, W.; Cutts, F.T.; Brown, D.W. An evaluation of oral-fluid collection devices for the determination of rubella antibody status in a rural Ethiopian community. Trans. R. Soc. Trop. Med. Hyg. 1998, 92, 679-685.

77. Nokes, D.J.; Nigatu, W.; Abebe, A.; Messele, T.; Dejene, A.; Enquselassie, F.; Vyse, A.; Brown, W.; Cutts, F.T. A comparison of oral fluid and serum for the detection of rubella-specific antibodies in a community study in Addis Ababa, Ethiopia. Trop. Med. Int. Health 1998, 3, 258-267.

78. Ramsay, M.E.; Brugha, R.; Brown, D.W.; Cohen, B.J.; Miller, E. Salivary diagnosis of rubella: A study of notified cases in the United Kingdom, 1991-1994. Epidemiol. Infect. 1998, 120, 315-319.

79. Vyse, A.J.; Brown, D.W.; Cohen, B.J.; Samuel, R.; Nokes, D.J. Detection of rubella virus-specific immunoglobulin $\mathrm{G}$ in saliva by an amplification-based enzyme-linked immmunosorbent assay using monoclonal antibody to fluorescein isothiocyanate. J. Clin. Microbiol. 1999, 37, 391-395. 
80. Gay, N.J.; Vyse, A.J.; Enquselassie, F.; Nigatu, W.; Nokes, D.J. Improving sensitivity of oral fluid testing in IgG prevalence studies: Application of mixture models to a rubella antibody survey. Epidemiol. Infect. 2003, 130, 285-291.

81. Ben Salah, A.; Zaâtour, A.; Pomery, L.; Cohen, B.J.; Brown, D.W.; Andrews, N. Validation of a modified commercial assay for the detection of rubella-specific IgG in oral fluid for use in population studies. J. Virol. Methods 2003, 114, 151-158.

82. Christopher Maple, P.A.; Jones, C.S. Time-resolved fluorometric immunoassay for rubella antibody-A useful method for surveillance studies. Vaccine 2002, 20, 1378-1382.

83. Centers for Disease Control and Prevention (CDC). Recommendations from an ad hoc meeting of the WHO measles and rubella laboratory network (LabNet) on use of alternative diagnostic samples for measles and rubella surveillance. Morb. Mortal. Wkly. Rep. 2008, 57, 657-660.

84. Banatvala, J.E.; Brown, D.W. Rubella. Lancet 2004, 363, 1127-1137.

85. Shirley, J.A.; Revill, S.; Cohen, B.J.; Buckley, M.M. Serological study of rubella-like illnesses. J. Med. Virol. 1987, 21, 369-379.

86. Miller, E.; Waight, P.; Gay, N.; Ramsay, M.; Vurdien, J.; Morgan-Capner, P.; Hesketh, L.; Brown, D.; Tookey, P.; Peckham, C. The epidemiology of rubella in England and Wales before and after the 1994 measles and rubella vaccination campaign: Fourth joint report from the PHLS and the National Congenital Rubella Surveillance Programme. Commun. Dis. Rep. 1997, 7, R26-R32.

87. Manikkavasagan, G.; Bukasa, A.; Brown, K.E.; Cohen, B.J.; Ramsay, M.E. Oral fluid testing during 10 years of rubella elimination, England and Wales. Emerg. Infect. Dis. 2010, 16, 1532-1538.

88. De Oliveira, S.A.; Siqueira, M.M.; Brown, D.W.; Litton, P.; Camacho, L.A.B.; Castro, S.T.; Cohen, B.J. Diagnosis of rubella infection by detecting specific immunoglobulin $\mathrm{M}$ antibodies in saliva samples: A clinic-based study in Niterói, RJ, Brazil. Rev. Soc. Bras. Med. Trop. 2000, 33, 335-339.

89. Vijaylakshmi, P.; Muthukkaruppan, V.R.; Rajasundari, A.; Korukluoglu, G.; Nigatu, W.; Warrener, L.A.; Samuel, D.; Brown, D.W. Evaluation of a commercial rubella IgM assay for use on oral fluid samples for diagnosis and surveillance of congenital rubella syndrome and postnatal rubella. J. Clin. Virol. 2006, 265-268.

90. Vyse, A.J.; Jin, L. An RT-PCR assay using oral fluid samples to detect rubella virus genome for epidemiological surveillance. Mol. Cell. Probes 2002, 16, 93-97.

91. Vauloup-Fellous, C.; Hübschen, J.M.; Abernathy, E.S.; Icenogle, J.; Gaidot, N.; Dubreuil, P.; Parent-du-Chaâtelet, I.; Grangeot-Keros, L.; Muller, C.P. Phylogenetic analysis of rubella viruses involved in congenital rubella infections in France between 1995 and 2009. J. Clin. Microbiol. 2010, 48, 2530-2535.

92. Abernathy, E.; Cabezas, C.; Sun, H.; Zheng, Q.; Chen, M.-H.; Castillo-Solorzano, C.; Ortiz, A.C.; Osores, F.; Oliveira, L.; Whittembury, A.; et al. Confirmation of rubella within 4 days of rash onset: Comparison of rubella virus RNA detection in oral fluid with immunoglobulin M detection in serum or oral fluid. J. Clin. Microbiol. 2009, 47, 182-188.

93. Rota, P.A.; Brown, K.E.; Hübschen, J.M.; Muller, C.P.; Icenogle, J.; Chen, M.-H.; Bankamp, B.; Kessler, J.R.; Brown, D.W.; Bellini, W.J.; et al. Improving global virologic surveillance for measles and rubella. J. Infect. Dis. 2011, 204, S506-S513. 
94. Kudesia, G.; Partridge, S.; Farrington, C.P.; Soltanpoor, N. Changes in age related seroprevalence of antibody to varicella zoster virus: Impact on vaccine strategy. J. Clin. Pathol. 2002, 55, 154-155.

95. Manikkavasagan, G.; Dezateux, C.; Wade, A.; Bedford, H. The epidemiology of chickenpox in UK 5-year olds: An analysis to inform vaccine policy. Vaccine 2010, 28, 7699-7705.

96. Miller, E.; Marshall, R.; Vurdien, J. Epidemiology, outcome and control of varicella-zoster infection. Rev. Med. Microbiol. 1993, 4, 222-230.

97. Tunbridge, A.J.; Breuer, J.; Jeffery, K.J.M.; British Infection Society. Chickenpox in adultsClinical management. J. Infect. 2008, 57, 95-102.

98. Daley, A.J.; Thorpe, S.; Garland, S.M. Varicella and the pregnant woman: Prevention and management. Aust. N. Zeal. J. Obstetr. Gynaecol. 2008, 48, 26-33.

99. Breuer, J. Vaccination to prevent varicella and shingles. J. Clin. Pathol. 2001, 54, 743-747.

100. Brisson, M.; Edmunds, W.J.; Gay, N.J. Varicella vaccination: Impact of vaccine efficacy on the epidemiology of VZV. J. Med. Virol. 2003, 70, S31-S37.

101. Joint Committee on Vaccination and Immunisation (JCVI) Sub-committee on Adolescent Vaccinations. Minutes of Meeting Held on 27 January 2012. Available online: http://www.wp.dh.gov.uk/transparencyfiles/2012/JCVI-Minutes-of-sub-committee-on-adolescentvaccinations-27-January-2012.pdf (accessed on 26 May 2015).

102. Vyse, A.J.; Gay, N.J.; Hesketh, L.M.; Morgan-Capner, P.; Miller, E. Seroprevalence of antibody to varicella zoster virus in England and Wales in children and young adults. Epidemiol. Infect. 2004, 132, 1129-1134.

103. Williams, V.; Gershon, A.A.; Brunell, P.P. Serologic response to varicella-zoster membrane antigens measured by indirect immunofluorescence. J. Infect. Dis. 1974, 130, 669-672.

104. Mohanty, S.; Perella, D.; Jumaan, A.; Robinson, D.; Forke, C.M.; Schmid, D.S.; Renwick, M.; Mankodi, F.; Watson, B.; Fiks, A.G. Validity of medical record documented varicella-zoster virus among unvaccinated cohorts. Hum. Vaccines Immunother. 2013, 9, 1735-1738.

105. Gershon, A.A.; Krugman, S. Seroepidemiologic survey of varicella: Value of specific fluorescent antibody test. Pediatrics 1975, 56, 1005-1008.

106. Maple, P.A.C.; Gray, J.; Breuer, J.; Kafatos, G.; Parker, S.; Brown, D. Performance of a time-resolved fluorescence immunoassay for measuring varicella-zoster virus immunoglobulin $\mathrm{G}$ levels in adults and comparison with commercial enzyme immunoassays and Merck glycoprotein enzyme immunoassay. Clin. Vaccine Immunol. 2006, 13, 214-218.

107. Chris Maple, P.A.; Gray, J.; Brown, K.; Brown, D. Performance characteristics of a quantitative, standardised varicella zoster IgG time resolved fluorescence immunoassay (VZV TRFIA) for measuring antibody following natural infection. J. Virol. Methods 2009, 157, 90-92.

108. Linder, N.; Ferber, A.; Kopilov, U.; Smetana, Z.; Barzilai, A.; Mendelson, E.; Sirota, L. Reported exposure to chickenpox: A predictor of positive anti-varicella-zoster antibodies in parturient women. Fetal Diagn. Ther. 2001, 16, 423-426.

109. Koturoglu, G.; Kurugol, Z.; Turkoglu, E. Seroepidemiology of Varicella-zoster virus and reliability of varicella history in Turkish children, adolescents and adults. Pediatr. Perinat. Epidemiol. 2011, $25,388-393$. 
110. Vandersmissen, G.; Moens, G.; Vranckx, R.; de Schryver, A.; Jacques, P. Occupational risk of infection by varicella zoster virus in Belgian healthcare workers: A seroprevalence study. Occup. Environ. Med. 2000, 57, 621-626.

111. Heininger, U.; Baer, G.; Bonhoeffer, J.; Schaad, U.B. Reliability of varicella history in children and adolescents. Swiss Med. Wkly. 2005, 135, 252-255.

112. Christiansen, D.; Barnett, E.D. Comparison of varicella history with presence of varicella antibody in refugees. Vaccine 2004 22, 4233-4237.

113. Kavaliotis, J.; Petridou, S.; Karabaxoglou, D. How reliable is the history of chickenpox? Varicella serology among children up to 14 years of age. Int. J. Infect. Dis. 2003, 7, 274-277.

114. Field, N.; Amirthalingam, G.; Waight, P.; Andrews, N.; Ladhani, S.N.; van Hoek, A.J.; Maple, P.A.C.; Brown, K.E.; Miller, E. Validity of a reported history of chickenpox in targeting varicella vaccination at susceptible adolescents in England. Vaccine 2014, 32, 1213-1217.

115. De Juanes, J.R.; Gil, A.; San-Martin, M.; Gonzalez, A.; Esteban, J.; Garcia de Codes, A. Seroprevalence of varicella antibodies in healthcare workers and health sciences students. Reliability of a self-reported history of varicella. Vaccine 2005, 23, 1434-1436.

116. Harel, Z.; Ipp, L.; Riggs, S.; Vaz, R.; Flanagan, P. Serotesting versus presumptive varicella vaccination of adolescents with a negative or uncertain history of chickenpox. J. Adolesc. Health 2001, 28, 26-29.

117. Stekler, J.D.; O’Neal, J.D.; Lane, A.; Swanson, F.; Maenza, J.; Stevens, C.; Coombs, R.W.; Dragavon, J.A.; Swenson, P.D.; Golden, M.R.; et al. Relative accuracy of serum, whole blood, and oral fluid HIV tests among Seattle men who have sex with men. J. Clin. Virol. 2013, 58, e119-e122.

(C) 2015 by the authors; licensee MDPI, Basel, Switzerland. This article is an open access article distributed under the terms and conditions of the Creative Commons Attribution license (http://creativecommons.org/licenses/by/4.0/). 